\title{
Correction to: A reactive oxygen species scoring system predicts cisplatin sensitivity and prognosis in ovarian cancer patients
}

Chaoyang Sun ${ }^{1,2 \dagger}$, Ensong Guo ${ }^{1,2 \dagger}$, Bo Zhou ${ }^{1,2}$, Wanying Shan ${ }^{1,2}$, Jia Huang ${ }^{1,2}$, Danhui Weng ${ }^{1,2}$, Peng Wu ${ }^{1,2}$, Changyu Wang ${ }^{1,2}$, Shixuan Wang ${ }^{1,2}$, Wei Zhang ${ }^{1,2}$, Qinglei Gao ${ }^{1,2}$, Xiaoyan Xu ${ }^{1,2}$, Beibei Wang ${ }^{1,2}$, Junbo Hu $u^{1,3}$, Ding $\mathrm{Ma}^{1,2}$ and Gang Chen ${ }^{1,2^{*}}$

\section{Correction to: BMC Cancer \\ https://doi.org/10.1186/s12885-019-6288-7}

Following publication of the original article [1], the authors reported an error in Fig. 1f.

The representative image of CD34 in cDDP+PIPER tumors (Fig. 1f, at the top-right corner) was inadvertently used incorrectly during the assembly and formatting of the images. The corrected Fig. 1 is presented in this correction article. The authors apologise for the error.

\begin{abstract}
Author details
${ }^{1}$ Cancer Biology Research Center (Key laboratory of Chinese Ministry of Education), Tongji Hospital, Tongji Medical College, Huazhong University of Science and Technology, Wuhan, People's Republic of China. ${ }^{2}$ Department of Gynecology and Obstetrics, Tongji Hospital, Tongji Medical College, Huazhong University of Science and Technology, Wuhan, People's Republic of China. ${ }^{3}$ Department of Surgery, Tongji Hospital, Tongji Medical College, Huazhong University of Science and Technology, Wuhan, People's Republic of China.
\end{abstract}

Published online: 12 March 2020

\section{Reference}

1. Sun C, Guo E, Zhou B, et al. A reactive oxygen species scoring system predicts cisplatin sensitivity and prognosis in ovarian cancer patients. BMC Cancer. 2019;19:1061 https://doi.org/10.1186/s12885-019-6288-7.

The original article can be found online at https://doi.org/10.1186/s12885019-6288-7

*Correspondence: gumpc@126.com

${ }^{\dagger}$ Chaoyang Sun and Ensong Guo contributed equally to this work.

'Cancer Biology Research Center (Key laboratory of Chinese Ministry of Education), Tongji Hospital, Tongji Medical College, Huazhong University of Science and Technology, Wuhan, People's Republic of China

${ }^{2}$ Department of Gynecology and Obstetrics, Tongji Hospital, Tongji Medical College, Huazhong University of Science and Technology, Wuhan, People's Republic of China

Full list of author information is available at the end of the article

(c) The Author(s). 2020 Open Access This article is licensed under a Creative Commons Attribution 4.0 International License, which permits use, sharing, adaptation, distribution and reproduction in any medium or format, as long as you give appropriate credit to the original author(s) and the source, provide a link to the Creative Commons licence, and indicate if changes were made. The images or other third party material in this article are included in the article's Creative Commons licence, unless indicated otherwise in a credit line to the material. If material is not included in the article's Creative Commons licence and your intended use is not permitted by statutory regulation or exceeds the permitted use, you will need to obtain permission directly from the copyright holder. To view a copy of this licence, visit http://creativecommons.org/licenses/by/4.0/. The Creative Commons Public Domain Dedication waiver (http://creativecommons.org/publicdomain/zero/1.0/) applies to the data made available in this article, unless otherwise stated in a credit line to the data. 


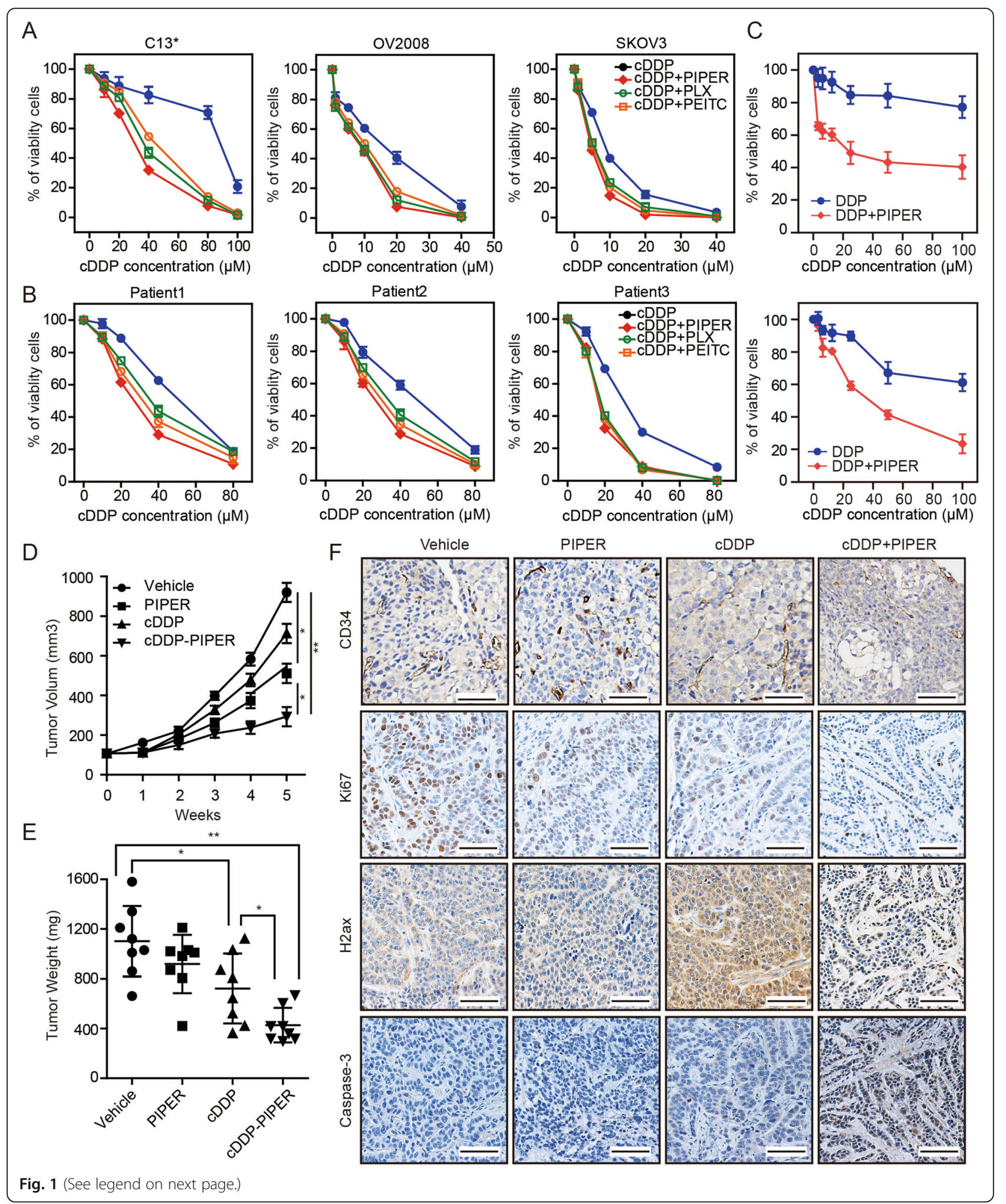


(See figure on previous page.)

Fig. 1 ROS levels are associated with CDDP sensitivity of ovarian cancer. a CDDP IC50 curves for ovarian cancer cell lines C13*, OV2008 and SKOV3 with or without ROS-elevating drugs (PLX4032, $1 \mu \mathrm{M}$, Piperlongumine (PIPER, $10 \mu \mathrm{M})$ and $\beta$-phenylethyl isothiocyanate (PEITC, $10 \mu \mathrm{M})$ ). b Cell viability of 3 strains of primary cancer cells was assayed after treatment with increasing concentrations of cDDP with or without ROS-elevating drugs for $48 \mathrm{~h}$ by CCK-8. c Cell viability of primary cancer cells derived from patients with recurrent ovarian cancer or primary ovarian cancer was assayed after treatment with increasing concentrations of cDDP with or without PIPER for $48 \mathrm{~h}$ by CCK- 8 . a-c The two-tailed $P$-values $<0.05$ were considered to indicate statistically significant differences. The results were tested by three independent experiments. $\mathbf{d}$ Growth curves of $\mathrm{C} 13^{*}$ subcutaneous xenograft tumors treated with vehicle, CDDP ( $2 \mathrm{mg} / \mathrm{kg}$, intraperitoneally every 4 days), PIPER ( $2 \mathrm{mg} / \mathrm{kg}$, intraperitoneally daily for 28 consecutive days), and CDDP plus PIPER (same dose as used in the single-agent groups) are shown. Tumor volumes were calculated as length $\times$ (square of width) $/ 2 . n=8$ per group. $\left({ }^{*} P<.05,{ }^{*} P<.001\right.$, two-sided Student t-test). e Tumor weights in nude mice were measured on day 35 after tumor cell injection. $n=8$ per group. $\left({ }^{*} P<.05,{ }^{*} P<.001\right.$, two-sided Student t-test). $\mathbf{f}$ The immunohistochemistry analyses for caspase 3 ,

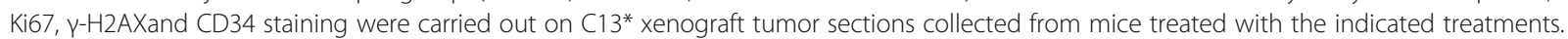
Representative staining is shown. Scale bars $=50 \mu \mathrm{m}$. Data in $(\mathbf{a}-\mathbf{e})$ are the mean values $\pm 95 \%$ confidence intervals 